\title{
Resistance to Beet Armyworm, Hemipterans, and Liriomyza spp. in Lycopersicon Accessions
}

\author{
Sanford D. Eigenbrode ${ }^{1}$ and John T. Trumble \\ Department of Entomology, University of California, Riverside, CA 92521 \\ Richard A. Jones \\ Department of Vegetable Crops, University of California, Davis, CA 95616
}

Additional index words. host plant resistance, tomatoes, Spodoptera exigua, Lycopersicon esculentum, Lycopersicon esculentum var. cerasiforme, Lycopersicon pimpinellifolium, Lycopersicon hirsutum f. glabratum

\begin{abstract}
Accessions of Lycopersicon esculentum var. cerasiforme (Dun.) A. Gray (cer) and L. pimpinellifolium (Jusl.) Mill. (pimp), sustained significantly less damage to fruit by beet armyworm [Spodoptera exigua (Hiibner)] than standard cultivars and breeding lines of $L$. esculentum Mill. (esc) under natural infestations in 1990 and 1991 in southern California. The dwarf vine cherry cultivar Tiny Tim also sustained less damage than the standards. Accessions of esc with various monogenic mutations sustained at least as much beet armyworm damage as did standard cultivars. The percentage of fruit damaged was significantly correlated with vine weight, weight per fruit, number of fruit, and the fruit-foliage weight ratio (Pearson's coefficients, respectively: $\mathbf{- 0 . 5 3 3 , 0 . 4 5 0 , - 0 . 4 8 3 , 0 . 3 9 0 , ~} \mathbf{n}=37$ ). In laboratory assays, survival of beet armyworm was significantly lower $(5 \%$ of susceptible\& growth rates were significantly lower, and development time was significantly longer on the fruit of resistant 'Tiny Tim' and LA $1320 \mathrm{cer}$ than the fruit of 11 other test lines. There were no substantial differences in beet armyworm survival on the foliage of the test lines. In the field trials, there were also significant differences among the test lines in damage by Liriomyza species and hemipteran pests. Lines with genes for increased densities of nonglandular leaf trichomes (especially LA 1663) were generally less damaged by Liriomyza than other lines. Damage by hemipterans was correlated with vine and fruit size, fruit count, and fruit-foliage weight ratio in 1991, but high intraseason variability prevented clear identification of test lines resistant to these pests.
\end{abstract}

Important insect pests of tomato in California and Mexico include the beet armyworm, the dipteran leafminers [ Liriomyza sativae Blanchard and L. trifolium (Burgess)], and a complex of hemipterans including several species of pentatomid bugs [ Euschistus conspersus Uhler, Chlorochroa spp., Thyanta pallidovirens (Stol.), and Nezara viridula (L.)], the tomato bug [ Cyrtopeltis modesta (Distant)], and the lygus bug [ Lygus lineolaris (P. de B.)]. Heavy use of insecticides to control these pests has resulted in the development of resistance in some pest populations (Brewer and Trumble, 1991), enhancement of the destructiveness of the leafminer due to loss of its natural enemies (Oatman and Kennedy, 1976), and may also pose environmental problems. In the major tomato growing regions of the United States, insecticide resistance development and loss of registered compounds limits the options available to producers for insect control (Georghiou, 1986). Therefore, development and deployment of cultivars with resistance to the important insect pests of tomato are needed.

Sources of resistance to some arthropods, including the beet armyworm and Liriomyza species, have been identified in accessions of L. hirsutum (f. typicum Humb. \& Bonpl. or f. gluabratum Mull.), but complicated inheritance of the resistance traits, undesirable linkages, or both, have hampered efforts to incorporate this resistance into L. esculentum breeding lines and cultivars (Farrar and Kennedy, 1992). These problems are likely to be less severe with resistance derived from L. esculentum or L.e. var. cerasiforme, but potential sources identified in these taxons (Cantelo et al., 1974; Elliger et al., 1981; Fery and Cuthbert, 1973, 1974, Juvik and

Received for publication 6 Apr. 1992. Accepted for publication 23 Nov. 1993. We thank W.G. Carson, L. Robinson, K. White. and E. Younce for technical assistance, and M.M. Diawara, G.G. Kennedy, J.M. Schalk, and three anonymous reviewers for helpful reviews of of the manuscript. Funding for the research was provided by the California Tomato Board. The cost of publishing this paper was defrayed in part by the payment of page charges. Under postal regulations, this paper therefore must be hereby marked advertisement solely to indicate this fact.

'To whom reprint requests should be addressed.
Stevens, 1982) have received little attention because the intensity of this resistance is less than in L. hirsutum. However, the difficulties with $L$. hirsutum sources, and the potential benefits of even partial resistance, justify renewed search within $L$. esculentum.

We report here the results of a 2-year study to evaluate the resistance to beet armyworm, hemipterans, and leafminer in genotypes of L. esculentum, $L$. e. var. cerasiforme, and $L$. pimpinellifolium. The test lines were evaluated for damage in the field under natural infestations in southern California. The beet armyworm was studied further in laboratory bioassays because of its considerable importance as a pest of fresh-market tomatoes, especially in California and Mexico (Brewer et al., 1990), and because relative susceptibilities were most consistent between the 2 years of the field study.

\section{Materials and Methods}

Field trials. Test entries were of five types (Table 1): 1) $L$. esculentum (esc) genotypes from C.M. Rick's LA series with monogenic traits considered likely to confer resistance, 2) wild $L$. esculentum var. cerasiforme types collected in Mexico (MW) in 1988 by R.A.J., 3) additional LAs, including L. e. var. cerasiforme (cer) and L. pimpinellifolium (pimp) entries (cer LA 292 has the Od monogenic trait), 4) a known resistant L. hirsutum f glabratum ( gla) as a negative check, and 5) standard tomato cultivars or parental lines. For simplicity, we will refer to all entries as "lines", although they include commercial varieties and wild accessions. Thirty-four lines were tested in 1990; in 1991, five additional standard cultivars were added. Test plants were germinated in the greenhouse and then transplanted as 8-week-old seedlings on 12 July 1990, and 10 June 1991, at the Univ. of California, South Coast Research and Education Center, Santa Ana. The planting was a randomized-block design with four blocks. Plots were single rows of five plants, spaced $40 \mathrm{~cm}$ within row and $2 \mathrm{~m}$ between rows in 1990 and $4 \mathrm{~m}$ between rows in 1991. The soil was a Sorranto 
loam, fertilized preplanting with $15 \mathrm{~N}-20 \mathrm{P}-0 \mathrm{~K}$ at $55 \mathrm{~kg}$ of $\mathrm{N}$ per hectare. Plants were maintained under standard cultural practices, unstaked, and drip-irrigated. Irrigation water contained $\mathrm{NO}_{3}$ at 2.5 $\mathrm{kg} \mathrm{N} / \mathrm{ha}$ per week.

During the season, infestations of beet armyworm and leafminers were assessed weekly ( 1990) or every 2 weeks (1991) on all lines. In each plot, 3-min counts were taken of the number of beet armyworm larvae and the number of leaves with at least one Liriomyza spp. mine. At harvest (16-18 Oct. 1990 and 10-20 Sept. 1991), 50 (1990) or 100 (1991) ripe fruit from each plot were evaluated for percentage of fruit damaged by beet armyworm, tomato fruitworm [Helicoverpa zea (Boddie)], tomato pinworm [ Kieferia lycopersicella (Walsingham)], and hemipterans (pentatomids, tomato bugs, and lygus). A fruit was considered damaged if there was any sign of feeding. Experience permitted distinguishing among damage from different lepidopteran larvae. Damage by sucking insects was difficult to distinguish and was pooled.

Fruit and vine characteristics were also measured in 1991 to test for associations between these and insect susceptibility. Vine weight, total weight of red and immature fruit, and total number of red and green fruit were determined for one plant from each replicate plot. Fruit counts were impractical for some of the wild accessions because of the many fruit per vine. Therefore, in all but the first block, in which all fruit were counted, the number of fruit per vine was estimated as follows: The number and weight of the fruit and weight of vine from a single branch of the plant were determined. The total weight and number of fruit per plant were then estimated, based on the single vine sample and the weight of the entire vine. Relationships between damage to fruit and vine weight, total weight of fruit, total number of fruit, and the fruitfoliage weight ratio were examined with correlation and regression analyses.

Laboratory bioasssays. Survival and development of beet armyworm larvae were determined on fruit and foliage of 14 of the 40 lines tested in the field. The lines included five cultivars or breeding lines, three esc LAs with mutant genes, three from the MW collection, one cer and one pimp LA, and the gla PI 126449. These were germinated in the greenhouse on 15 Jan 1991, and transplanted into the field at the Univ. of California, Riverside, on 8 Apr. Plants were spaced $40 \mathrm{~cm}$ within the row and $2 \mathrm{~m}$ between rows, and furrow irrigated twice weekly. The soil was an Arlington loam, pretreated with $16 \mathrm{~N}-20 \mathrm{P}-0 \mathrm{~K}$ at $450 \mathrm{~kg} \cdot \mathrm{ha}^{-1}$.

During April and May 1991, beet armyworm larvae were reared individually from first instar to pupation in 30-ml plastic cups on leaves from each of the 14 lines using the bioassay method of Diawara et al. (1992). Each cup had $5 \mathrm{ml}$ of nonnutrient agar gel in the bottom to maintain moisture. Cup lids were punctured to provide ventiliation. Fresh leaf material from the fourth to fifth node from the terminal of the field-grown plants was added to the cups on alternate days. The cups were placed in rearing chambers at $28 \mathrm{C}, 16 \mathrm{~h}$ light $/ 8 \mathrm{~h}$ dark and ambient humidity. Survival (\%) to pupation, days to pupation, days to adult emergence, and larval weights during development were measured. Relative larval growth rates (mg/ mg larva/ day) were calculated as:

$$
\frac{\text { weight day } 9 \text {-weight day } 3}{\text { average weight over the } 6 \text { days }} / 6 \text { days }
$$

Ten larvae constituted a replication, and two replications of each line were run simultaneously in separate chambers. The whole test was repeated three times, for a total of six replications per line.
Data from the three tests were combined for analysis.

Beet armyworm were also reared in groups of seven larvae, on green fruit ( $\approx 5$ weeks after anthesis) in 0.47 liter cardboard cans. The test included all lines from the foliage test, except the gla entry. Fruit ( 1 to 4 depending on size of fruit) were replaced in the cans every 2 to 3 days, and the cans were lined with toweling moistened with distilled water. Rearing chamber conditions were the same as for foliage tests. Larvae were reared from third instar to pupation because larvae normally do not feed on fruit before third instar in the field, and survival of earlier instars is extremely low even on susceptible fruit (S. Eigenbrode, unpublished data). Green fruit was chosen for the assay because the fruit are harvested commercially at the onset of ripening. Survival at pupation was recorded. Average larval relative growth was determined based on the average weight of all the larvae in a replication at 0 and 9 days from the start of the test. Each group of seven larvae was considered a replication. The test was run once and included 10 replications per line. Dates of pupation and adult emergence were recorded for individual larvae. Days to pupation and emergence were analyzed with individual larvae as replications within each test line.

Fruit cuticle toughness was measured on the 13 lines used in the fruit bioassay to examine its relationship to beet armyworm survival. Measurements were made at the beginning of the fruit feeding bioassay using fruit 5 weeks after anthesis. Blossoms were tagged and dated at anthesis to determine age of fruit. The measurements were made with a UCR fruit firmness penetrometer (Coggins and Lewis, 1965), which measures the force required to puncture the fruit cuticle with a 1-mm drill blank. A mean value (newtons) was determined for each fruit based on four penetrations equally spaced around the equator of the fruit. Ten fruit were measured from each line. The relationship between survival on fruit and cuticle toughness, expressed as resistance to penetration, was then examined with regression analysis.

Statistics. All statistical procedures were performed in SAS (SAS Institute, 1990). The procedure CORR was used for correlations and the procedure GLM was used for regression and ANOVA. Transformations were performed as needed to meet the assumptions of the tests (see footnotes of tables). ANOVA was performed on combined ranks of infestation by beet armyworm in both years, providing the equivalent of a Kruskal-Wallis test (Sokal and Rohlf, 1981) for differences among means.

\section{Results}

Damage and pest densities. Damage by all insects and densities of beet armyworm were much lower in the atypically cool Summer 1991 than in 1990. There was a significant effect of year for all these statistics $(P<0.0001)$. Individual ANOVA's were, therefore, performed for each year.

The percentage of fruit damaged by beet armyworm differed significantly among the lines in both years (Table 1). Although there was a significant line $\times$ year interaction $(\mathrm{F}=4.6 ; P=0.0001)$, ranks of percentage of damaged fruit from both years were correlated ( $r=0.615, P=0.0002, \mathrm{n}=32$ ), indicating relative susceptibility was somewhat stable across year. The mean ranks for the lines combined over both years were significantly different based on Kruskal-Wallis (Table 1).

The small-fruited types, cer, pimp, and the gla entry, were less damaged than larger-fruited types and standards in both years (Table 1). PI 126449 (L. hirsutum) and MW 4 had no damaged fruit in either season. MW 1-4, MW 18, LA 1320, LA 1645, had consistently low damage in both years.

Lycopersicon esculentum genotypes with monogenic mutants 
Table 1. Percentage of fruit damaged by beet armyworm and hemipterans, and number of leaves per plant with Liriomyza spp. mines on tomato test lines under natural infestations at the South Coast Research and Education Center, Santa Ana, Calif., in 1990 and 1991.

\begin{tabular}{|c|c|c|c|c|c|c|c|c|}
\hline \multirow[b]{2}{*}{ Test lines ${ }^{7}$} & \multirow[b]{2}{*}{ Mutant IDs: } & \multicolumn{3}{|c|}{$\begin{array}{c}\text { Beet armyworm } \\
\text { damage }\end{array}$} & \multicolumn{2}{|c|}{$\begin{array}{c}\text { Hemipteran } \\
\text { damage }\end{array}$} & \multicolumn{2}{|c|}{$\begin{array}{l}\text { Liriomyza } \\
\text { leaf mines }\end{array}$} \\
\hline & & $1990^{x}$ & $1991^{\prime \prime}$ & Rank' & $1990^{u}$ & $1991^{\prime}$ & $1990^{5}$ & $1991^{\prime}$ \\
\hline \multicolumn{9}{|l|}{$L A s$ or $P / s$} \\
\hline LA 291 esc r & $\mathrm{ms}-2, /+; \mathrm{a}, \mathrm{hl}$ & --- & $2.3 b-f$ & & --- & $2.0 \mathrm{i}-\mathrm{k}$ & $2.6 \mathrm{j}-\mathrm{m}$ & $0.2 \mathrm{~d}-\mathrm{f}$ \\
\hline LA 499 esc & Od, at, cm/t, sn, t & $8.5 \mathrm{e}-\mathrm{g}$ & $2.0 b-f$ & 80.7 & $8.0 \mathrm{hi}$ & $10.0 \mathrm{c}-\mathrm{i}$ & $8.6 c-1$ & $1.8 \mathrm{~b}-\mathrm{e}$ \\
\hline LA 3-71 esc 1 & Ln & $16.0 \mathrm{de}$ & $3.2 \mathrm{~b}-\mathrm{f}$ & 89.5 & $35.5 \mathrm{a}-\mathrm{f}$ & $9.7 \mathrm{~d}-\mathrm{j}$ & $17.4 a b$ & $2.1 \mathrm{bc}$ \\
\hline LA 1430 esc : & sy, Ln. bls, sf & $20.2 \mathrm{~cd}$ & $5.3 \mathrm{~b}$ & 93.2 & $6.8 \mathrm{i}$ & $3.5 \mathrm{~h}-\mathrm{k}$ & $4.5 \mathrm{~g}-\mathrm{m}$ & $2.6 \mathrm{~b}$ \\
\hline LA 1663 esc I & Ln, Wom & --- & & & --- & --- & 0.0 & 0.0 \\
\hline LA 754 esc & m. d, p. aw & -- & --- & & --- & --- & $3.8 \mathrm{i}-\mathrm{m}$ & $0.1 \mathrm{ef}$ \\
\hline LA 986 esc & $\begin{array}{l}\text { s, bk. Wom }, o \\
\text { aw, p, d }\end{array}$ & $47.3 \mathrm{a}$ & $16.8 \mathrm{a}$ & 113.2 & $40.8 \mathrm{a}-\mathrm{c}$ & $22.8 \mathrm{a}-\mathrm{c}$ & $2.4 \mathrm{k}-\mathrm{m}$ & $0.6 \mathrm{c}-\mathrm{f}$ \\
\hline LA 53 esc & Wo/t & $11.5 \mathrm{~d}-\mathrm{f}$ & $4.3 \mathrm{~b}-\mathrm{d}$ & 85.6 & $13.0 \mathrm{f}-\mathrm{i}$ & $12.3 \mathrm{~b}-\mathrm{h}$ & $6.4 \mathrm{e}-\mathrm{m}$ & $0.6 c-f$ \\
\hline LA 85 esc & $W_{0} /+, d ; h$ & $33.6 \mathrm{~b}$ & $15.8 \mathrm{a}$ & 107.9 & $11.5 \mathrm{a}-\mathrm{f}$ & $15.5 \mathrm{a}-\mathrm{f}$ & $2.3 \mathrm{k}-\mathrm{m}$ & 0.1 ef \\
\hline LA 715 esc & Me, Wo, aw, d & $\ldots$ & --- & & -- & --- & $1.71 \mathrm{~m}$ & $0.3 \mathrm{~d}-\mathrm{f}$ \\
\hline LA 258 esc & $W_{o}^{m}$ & $27.7 b c$ & $14.3 \mathrm{a}$ & 105.3 & $27.7 \mathrm{~d}-\mathrm{h}$ & $22.5 \mathrm{a}-\mathrm{d}$ & $2.9 \mathrm{i}-\mathrm{m}$ & $1.0 \mathrm{~b}-\mathrm{f}$ \\
\hline LA 958 esc 1 & lop & $35.1 \mathrm{~b}$ & $18.3 \mathrm{a}$ & 110.0 & $57.5 \mathrm{ab}$ & $29.3 \mathrm{a}$ & $4.1 \mathrm{~h}-\mathrm{m}$ & 0.1 ef \\
\hline LA 1908 esc & $W o^{m z}$ & $38.5 \mathrm{ab}$ & $14.3 \mathrm{a}$ & 108.1 & $59.0 \mathrm{a}$ & $26.8 \mathrm{ab}$ & $1.71 \mathrm{~m}$ & $0.6 c-f$ \\
\hline LA 292 cer & Od & $6.5 \mathrm{fh}$ & $2.0 \mathrm{~b}-\mathrm{f}$ & 68.4 & --- & $2.5 \mathrm{~h}-\mathrm{k}$ & $10.6 \mathrm{~b}-\mathrm{j}$ & 0.0 \\
\hline LA 1203 rer & & $0.5 \mathrm{j}$ & $1.0 \mathrm{c}-\mathrm{f}$ & 40.4 & $33.0 \mathrm{~b}-\mathrm{f}$ & $3.8 \mathrm{i}-\mathrm{k}$ & $12.3 \mathrm{a}-\mathrm{g}$ & 0.1 ef \\
\hline LA 1313-1 cer & & $1.5 \mathrm{ij}$ & $2.0 \mathrm{~b}-\mathrm{f}$ & 55.9 & $54.0 \mathrm{a}-\mathrm{c}$ & $3.3 \mathrm{~h}-\mathrm{k}$ & $12.2 \mathrm{a}-\mathrm{h}$ & 0.1 ef \\
\hline LA 1606 pimp & & $3.5 \mathrm{~g}-\mathrm{j}$ & $0.3 \mathrm{f}$ & 52.6 & $31.0 \mathrm{c}-\mathrm{g}$ & $0.8 k$ & $4.7 \mathrm{f}-\mathrm{m}$ & $0.1 \mathrm{ef}$ \\
\hline LA 1320 cer & & 0.0 & $0.3 \mathrm{f}$ & 32.8 & $45.5 a-d$ & $1.5 \mathrm{i}-\mathrm{k}$ & $12.8 \mathrm{a}-\mathrm{f}$ & $1.0 \mathrm{~b}-\mathrm{f}$ \\
\hline LA $1205 \mathrm{cer}$ & & $0.8 \mathrm{ij}$ & $0.8 \mathrm{c}-\mathrm{f}$ & 51.5 & $26.5 \mathrm{~d}-1$ & $4.3 \mathrm{f}-\mathrm{k}$ & $7.3 \mathrm{~d}-\mathrm{m}$ & $1.6 \mathrm{~b}-\mathrm{f}$ \\
\hline LA $1286 c e r$ & & $5.5 f-1$ & $0.5 \mathrm{ef}$ & 54.4 & $16.5 \mathrm{e}-\mathrm{i}$ & $1.5 \mathrm{i}-\mathrm{k}$ & $15.1 \mathrm{a}-\mathrm{d}$ & $0.3 \mathrm{~d}-\mathrm{f}$ \\
\hline LA $1228 \mathrm{cer}$ & & $2.0 \mathrm{ij}$ & 0.0 & 35.1 & $43.0 \mathrm{a}-\mathrm{d}$ & $7.0 \mathrm{i}-1$ & $14.1 \mathrm{a}-\mathrm{c}$ & $0.6 \mathrm{c}-\mathrm{f}$ \\
\hline LA 1645 pimp & & 0.0 & 0.0 & 28.3 & $13.0 \mathrm{f}-\mathrm{i}$ & $1.8 \mathrm{i}-\mathrm{k}$ & $7.4 c-m$ & $0.1 \mathrm{ef}$ \\
\hline PI 126449 gla & & $0.0 \mathrm{f}-\mathrm{i}$ & 0.0 & 28.3 & 0.0 & 0.0 & $0.1 \mathrm{~m}$ & $0.1 \mathrm{ef}$ \\
\hline \multicolumn{9}{|l|}{ Collected in $1988^{9}$} \\
\hline MW l cer & & $1.0 \mathrm{ij}$ & 0.0 & 33.6 & $41.0 \mathrm{a}-\mathrm{e}$ & $0.3 \mathrm{kl}$ & $19.4 a$ & $1.1 \mathrm{~b}-\mathrm{f}$ \\
\hline MW 2 cer & & $0.5 \mathrm{j}$ & 0.0 & 32.4 & $41.5 \mathrm{a}-\mathrm{d}$ & 0.0 & $10.2 \mathrm{~b}-\mathrm{k}$ & $0.4 \mathrm{c}-\mathrm{f}$ \\
\hline MW 3 cer & & $0.5 \mathrm{j}$ & 0.0 & 32.4 & $31.0 \mathrm{c}-\mathrm{g}$ & 0.0 & $15.5 \mathrm{a}-\mathrm{c}$ & 0.1 ef \\
\hline MW 4 cer & & $0.0^{\circ}$ & 0.0 & 31.9 & $34.0 \mathrm{a}-\mathrm{f}$ & $34.0 \mathrm{jk}$ & $6.7 \mathrm{e}-\mathrm{m}$ & $0.3 \mathrm{~d}-\mathbf{f}$ \\
\hline MW 5 cer & & $1.5 \mathrm{ij}$ & 0.0 & 40.8 & $44.0 \mathrm{a}-\mathrm{c}$ & 0.0 & $8.9 c-1$ & $0.5 c-f$ \\
\hline MW 15 cer & & 0.0 & $0.5 \mathrm{ef}$ & 34.6 & $28.5 \mathrm{~d}-\mathrm{h}$ & $0.3 \mathrm{k}$ & $14.9 \mathrm{a}-\mathrm{d}$ & 0.0 \\
\hline MW 16 cer & & $2.0 \mathrm{~h}-\mathrm{j}$ & $0.3 \mathrm{f}$ & 43.1 & $27.5 \mathrm{~d}-\mathrm{h}$ & $1.3 \mathrm{jk}$ & $9.3 b-1$ & 0.0 \\
\hline MW $17 \mathrm{cer}$ & & 0.0 & $1.3 \mathrm{~b}-\mathrm{f}$ & 45.4 & $40.5 \mathrm{a}-\mathrm{d}$ & $5.8 \mathrm{f}-\mathrm{k}$ & $9.7 b-1$ & 0.0 \\
\hline MW 18 cer & & 0.0 & $0.3 \mathrm{f}$ & 32.8 & $11.5 \mathrm{~g}-\mathrm{i}$ & $0.5 \mathrm{k}$ & $9.4 b-1$ & $0.6 \mathrm{ef}$ \\
\hline MW 19 cer & & $0.5 \mathrm{j}$ & $1.5 \mathrm{~b}-\mathrm{f}$ & 53.5 & $30.5 \mathrm{c}-\mathrm{g}$ & $4.8 \mathrm{f}-\mathrm{k}$ & $10.8 \mathrm{~b}-\mathrm{i}$ & $0.6 \mathrm{ef}$ \\
\hline \multicolumn{9}{|c|}{ Cultivars and parentals } \\
\hline $\mathrm{UCN} 28$ esc & & $15.5 \mathrm{de}$ & $4.3 \mathrm{~b}$ & 93.3 & $26.0 \mathrm{~d}^{\circ}$ & $12.3 \mathrm{~b}-\mathrm{g}$ & $7.0 \mathrm{~d}-\mathrm{m}$ & $2.6 \mathrm{~b}$ \\
\hline 'VFN 7718' es & & $*$ & $3.5 b-f$ & & $*$ & $7.0 \mathrm{e}-\mathrm{k}$ & $*$ & $1.5 \mathrm{~b}-\mathrm{f}$ \\
\hline 'Tiny Tim' esc & & $*$ & $0.5 \mathrm{~d}-\mathbf{f}$ & & * & $18.1 \mathrm{a}-\mathrm{e}$ & $*$ & $1.1 \mathrm{~b}-\mathrm{f}$ \\
\hline 'Ace 55' esc & & $*$ & $3.3 b-f$ & & * & $8.8 \mathrm{~d}-\mathrm{j}$ & * & $2.4 \mathrm{~b}$ \\
\hline 'Bingo' esc & & $*$ & $4.3 \mathrm{~b}$ & & $*$ & $9.0 \mathrm{~d}-\mathrm{j}$ & $*$ & $2.5 \mathrm{~b}$ \\
\hline $512^{\circ} \mathrm{esc}$ & & * & $3.9 \mathrm{~b}-\mathrm{e}$ & & $*$ & $3.5 \mathrm{~g}-\mathrm{k}$ & * & $1.9 \mathrm{~b}-\mathrm{d}$ \\
\hline T5 ${ }^{\prime 4}$ esc & & $*$ & $4.0 \mathrm{bc}$ & & $*$ & $5.0 \mathrm{f}-\mathrm{k}$ & * & $5.6 \mathrm{a}$ \\
\hline
\end{tabular}

$\overline{{ }^{2} e s c}=$ Lycopersicon esculentum, cer $=L$. esculentum var. cerasiforme. pimp $=L$. pimpinellifolium, gla $=L$. hirsutum $\mathrm{f}$. glabratum.

$\mathrm{y}_{\mathrm{a}}=$ anthocyanless, $\mathrm{at}=$ apricot, $\mathrm{aw}=$ no anthocyanin, $\mathrm{bk}=$ beaked, bls $=$ baby lee syndrome, $\mathrm{cm}=$ curley mottled, $\mathrm{d}=\mathrm{dwarf}, \mathrm{hl}=\mathrm{hairless}, \mathrm{Ln}=\mathrm{lanata}$ (wooly type), lop = long jipes, $m=$ mottled, $\mathrm{Me}=$ mouse ears, $\mathrm{ms}-2=$ male sterile $2, o=$ ovate, $\mathrm{Od}=$ odorless, $\mathrm{p}=$ peach, $\mathrm{s}=$ compound inflorescence, sf $=$ solanifolia, $\mathrm{sn}=$ singed, $\mathrm{sy}=$ sunny, $\mathrm{t}=$ tangerine, $\mathrm{Wo}=$ wooly, $\mathrm{Wo}^{\mathrm{m}}=$ Morgan's wooly, $\mathrm{Wo}^{\mathrm{m} \iota}=$ Mcl Zobels's wooly.

${ }^{\times}$ANOVA $\mathrm{F}=3.26 ; P=0.0001, \mathrm{df}=27,111$.

${ }^{\mathrm{W}} \mathrm{ANOVA} \mathrm{F}=8.70 ; P=0.0001, \mathrm{df}=28,114$.

'Mean rank over both seasons, lower number ranks have less damage. Ranks significantly different $P=0.0001$ (Kruskal-Wallis test).

${ }^{4} \mathrm{ANOVA} \mathrm{F}=3.26 ; P=0.0001 ; \mathrm{df}=27,111$.

'ANOVA $F=4.25 ; P=0.0001 ; \mathrm{df}=31,126$.

${ }^{\mathrm{S}} \mathrm{ANOVA} F=3.17 ; \mathrm{P}=0.0001 ; \mathrm{df}=33,135$.

${ }^{\top}$ ANOVA F $=3.15 ; \mathrm{P}=0.0001 ; \mathrm{df}=39,159$.

${ }^{4}$ Catalogued under these IDs in the collection of R.A. Jones.

*, not included in 1990 trial; ---, insufficient fruit for analysis. Mean separation for all tests by LSD (0.05). Values without letters were excluded from analysis because of zero variance. Percentages were transformed to arcsin $\sqrt{x-1}$ before analysis. 
suffered similar or significantly greater damage by beet armyworm than standard types in both years. Among those producing sufficient fruit for analysis, LAs 291, 292, 499, 3-71, 1430, and 53 sustained similar damage as standard types. LAs 986, 85, 258, 958, and 1908 sustained significantly higher damage than standard types.

More larvae were observed on the plants in 1990 than in 1991 ( 0.84 vs. 0.14 larvae in $3 \mathrm{~min}$ count, respectively). There were no significant differences among the test lines in the number of beet armyworm larvae observed on the plants in either year $(1990 \mathrm{~F}=$ $1.26, \mathrm{df}=33,135, P=0.1936 ; 1991 \mathrm{~F}=0.920, \mathrm{df}=39,159, P=$ $0.6032)$.

Damage by sucking insects was significantly different among the lines in both years (Table 1). The most striking difference between the years was the high level of damage to small-fruited types ( cer and pimp) in 1990, contrasted with relatively low damage to these types in 1991. Damage to some lines differed substantially between the 2 years. For example, LA 85 was among the least damaged in 1990 and among the most damaged in 1991, and MW 5 was heavily damaged in 1990 but sustained no damage in 1991. This difference may reflect differences that our data cannot resolve in the composition of the hemipteran pest complex in the 2 years. Consistencies of interest are LA 958 and LA 1908, which were the most damaged in both years, and PI 126449 ( $g l a$ ), which was undamaged in either year. As occurred for beet armyworm, susceptibility to hemipteran damage of LAs with monogenic mutations was generally similar to standards. The smallfruited cultivar Tiny Tim, included only in 1991, sustained heavy damage as compared to wild small-fruited types.

The average number of leaf mines also differed significantly among the lines in both years (Table 1). Several lines performed very differently in the 2 years. In general, lines with genes for increased nonglandular trichomes (Wo types and Ln) were less attacked by leaf miners than other lines. LA 1663, which carries two such mutations, sustained no mining in either year.

Damage by tomato pinworm and tomato fruitworm were too low in both years to obtain meaningful separation of the test lines. The cer lines were consistently undamaged by these pests, but many standard lines also had zero damage in one or both years (data not presented).

Fruit and vine characteristics. The test lines differed significantly in the weight of individual fruit, weight of total fruit, weight of vine, fruit-foliage weight ratio, and number of fruit per vine (Table 2). Damage to fruit in the field due to beet armyworm and sucking insects was significantly correlated with all these fruit and vine characteristics (Table 3). Although significant, the correlation coefficients indicate that regressions on these variables explain $<25 \%$ of the variation in damage to fruit. The best potential predictor of beet armyworm damage among these variables was vine weight. Although the regression of damage on vine weight, using plot means, was significant $(\mathrm{F}=13.63 ; P=0.0003 ; \mathrm{df}=$ $1,113)$ it explained only $11 \%$ of the variation in beet armyworm damage. Vine weight had only a small effect when included in the model as a covariate with line as a determinant of beet armyworm damage (line $\mathrm{F}=7.35, P=0.0001$; vine weight $\mathrm{F}=1.07, P=0.304$ ). Thus, although whole-plant characteristics, such as vine weight, are associated with and may contribute todifferences in damage to fruit, other plant traits of the test lines are also important.

Laboratory bioassays. Larval survival differed significantly on foliage of the 14 lines tested in the laboratory assays (Table 4). but relative growth rate, days to pupation, and days to adult did not (all $\mathrm{P}$ values > 0.130). Survival was extremely low on $L$. hirsutum PI 126449 , as expected, and the effect of this line accounts for the significant $\mathrm{F}$ value of the ANOVA of survival. The differences in larval survival on foliage among other test lines were not great. Survival was significantly lower on foliage of LA 1320 than on other non- gla types, suggesting low levels of foliar antibiosis in this line. Survival on foliage of the 14 test lines, however, was not correlated with damage to fruit of these lines in the field $\left(R^{2}=\right.$ 0.068).

Beet armyworm larval survival was lower on fruit than on foliage (Table 4). Development times were longer and growth rates were lower on foliage than on fruit (days to pupation, 14.9 and 22.8; $\mathrm{mg} / \mathrm{mg} / \mathrm{larva} / \mathrm{day}, 0.271$ and 0.032 on foliage and fruit, respectively). Tomato fruit (5 weeks after anthesis) is evidently an inferior diet relative to foliage for beet armyworm. Larval survival and growth rates on fruit differed significantly among the 13 lines tested (Table 4). Differences in beet armyworm survival on the test lines were much greater on fruit than on foliage. As with foliage, survival on fruit was not correlated with damage to fruit in the field ( $R^{2}=0.156$ ). Nevertheless, very low survival and long developmental times on fruit of LA 1320 and 'Tiny Tim' suggest that the low damage on these lines may be due to unsuitability of the fruit for beet armyworm larvae.

The force required to penetrate fruit cuticles differed significantly among the lines (Table 4). The cuticle of resistant 'Tiny Tim' was significantly tougher $(P=0.05)$ than that of all other lines, and that of susceptible 'VFN 7718' was relatively easy to penetrate. The cuticle of resistant LA 1320 and susceptible 'Bingo', however, were intermediate. The correlation between cuticle toughness and survival of larvae among the 13 lines in the fruit test was not significant $\left(R^{2}=-0.527 ; P=0.064\right)$.

\section{Discussion}

The test lines of tomato may include sources of genetic resistance to beet armyworm. The lines sustaining less damage than standard cultivars were small-fruited types, a characteristic not compatible with the goals of most commercial breeding programs. Damage was positively correlated with weight of individual fruit and the fruit-foliage ratio, and negatively correlated with the total weight of the vine and the number of fruit on the vine. These four plant characteristics were also correlated with one another; there was a general tendency for smaller-fruited types to have larger,

Table 2. Characteristics of vine and fruit of the tomato test lines in 1991.

\begin{tabular}{lccccc}
\hline \hline Statistic & $\begin{array}{c}\text { Vine wt } \\
(\mathrm{kg})\end{array}$ & $\begin{array}{c}\text { Total fruit wt } \\
(\mathrm{kg})\end{array}$ & $\begin{array}{c}\text { Fruit : foliage } \\
\text { wt ratio }\end{array}$ & $\begin{array}{c}\text { No. of } \\
\text { fruit/vine }\end{array}$ & $\begin{array}{c}\text { Wt/fruit } \\
(\mathrm{g})\end{array}$ \\
\hline Mean & 4.70 & 6.47 & 1.52 & 1693 & 37.5 \\
Range & $0.8-9.3$ & $0.8-16.3$ & $0.57-4.33$ & $0-12763$ & $0.5-253.0$ \\
ANOVA F & 2.81 & 2.23 & 7.95 & 7.01 & 15.85 \\
df & 38,111 & 35,105 & 35,106 & 35,106 & 35,107 \\
Prob $>$ F & 0.0001 & 0.0009 & 0.0009 & 0.0001 & 0.0001 \\
\hline
\end{tabular}


heavier vines, more numerous fruit, and low damage. Low damage on small-fruited wild accessions may, therefore, be partly explained with the "dilution theory" of Canerday et al. (1969). That is, the insects are less likely to encounter fruit, and encounter a lower percentage of fruit, on large-vined plants with numerous small fruit, and smaller fruit-foliage ratio. At least one of these vine and fruit characteristics has been correlated with fruit damage by Helicoverpa zea and Heliothis armigera (Hübner) (Canerday et al., 1969; Fery and Cuthbert, 1973; Kashyap and Verma, 1986).

The correlations between damage and vine and fruit characteristics leave much of the variation unexplained. Biological mechanisms other than dilution presumably account for some of the resistance to beet armyworm. Certainly, this is true for 'Tiny Tim', which sustained the lowest damage of any commercial cultivar, but is a dwarf vine type with low vine weight and a high fruitfoliage ratio. Low beet armyworm survival and growth rates and long development times on fruit of 'Tiny Tim' and $L$. $e$. var. cerasiforme LA 1320 suggest that low susceptibility of these two lines is partly due to antibiosis or physical resistance to feeding on fruit. The fruit traits responsible for this resistance may be compatible with breeding programs.

The cuticle of 'Tiny Tim' fruit is significantly tougher than the cuticle of the other test lines, and this may reduce feeding efficiency by larvae. Larvae dying in the first few days after the test was started often did not penetrate the fruit and may have succumbed to starvation. Reduced survival of beet armyworm has previously been associated with tough fruit cuticle in an accession of L. e. var. cerasiforme and an accession of L. pimpinellifolium (Juvik and Stevens, 1982). but cuticle toughness has not been investigated as a potential resistance character.

LA 1320 fruit does not have a particularly tough cuticle, and antibiosis in this line may result from toxicity of the fruit tissue. Lycopersicon e. var. cerasiforme green fruit can have elevated levels of $\boldsymbol{\alpha}$ tomatine (Juvik et al., 1982, Juvik 1980). Alphatomatine has adverse effects on growth of Helicoverpa zea in artificial diet (Elliger et al., 1981; Farrar and Kennedy, 1990; Isman and Duffey, 1982) and is correlated with survival of $H$. zea on fruit (Juvik and Stevens, 1982). Although $\boldsymbol{\alpha}$-tomatine content of fruit was not correlated with beet armyworm survival in a previous study (Juvik and Stevens, 1982). concentrations in LA 1320 may be high enough to be antibiotic. Resistance dependent on high levels of alkaloids in fruit would not necessarily be incompatible with human consumption, since $\alpha$-tomatine levels decline as fruit ripens (Juvik and Stevens, 1982).

The laboratory bioassays indicate that foliar antibiosis is of minor importance in determining susceptibility to beet armyworm among the esc, cer, and pimp lines tested. The foliage of LA 1320 may have some antibiosis, but this is not especially strong. Only the foliage of the gla accession substantially reduced larval survival. The similar beet armyworm infestations among the lines in the field during both seasons are consistent with a lack of foliar antibiosis and also suggest that oviposition nonpreference is also not important.

Foliar susceptibility may not be inconsistent with breeding for at least partial levels of resistance to beet armyworm and possibly other fruit-damaging pests in tomatoes. Although the foliage of 'Tiny Tim' was very suitable for beet armyworm development, this cultivar sustained low damage in the field, presumably because of fruit-based resistance. 'Tiny Tim' foliage is also very suitable for survival of Helicoverpa zea larvae in laboratory assays (Sinha and McLaren, 1989) but sustains low damage in the field from this insect (Fery and Cuthbert, 1974). A form of tolerance can be envisioned in which damage to fruit is reduced, but insect populations on the plants are not suppressed. Tomatoes generally can tolerate substantial artificial defoliation without yield losses (Pasternak et al., 1979; Tanaka et al., 1974), making them suitable for such a strategy. As this type of resistance appears to occur in cultivar Tiny Tim, deliberate breeding for it may be feasible. The fruit of even susceptible tomatoes is much inferior to foliage for beet armyworm development (Table 4), and enhancing this differential may lead to economic levels of resistance. As with other types of tolerance, this type of resistance is advantageous because selection for pest adaptation is eliminated (Gould, 1984). But, tolerance may also be disadvantageous if generalist pests such as H. zea and S. exigua emigrate and attack nearby crops (Kennedy et al., 1987).

Our data on hemipteran damage also suggest that the dilution effect and physiological resistance traits contributed to resistance, at least in 1991. The variability in damage between the 2 years was so great, however, that additional field evaluations, which separate damage by the individual hemipteran pests, and laboratory studies, will be needed to determine if there is physiological resistance to hemipterans in any of the test lines.

Mutant genetic stocks tested include no potential sources of resistance to beet armyworm or hemipteran pests. Genotypes with mutant traits for reduced odor (Od), reduced trichome densities (hl), or reduced anthocyanin production ( $\mathrm{sn}, \mathrm{sy}, \mathrm{t}, \mathrm{a}, \mathrm{at}, \mathrm{bls}$ ) sustained damage similar to standard types. Five mutant genotypes sustained significantly more damage than standards. The vine characteristics of these mutants were not substantially different from those of standard controls, nor were beet armyworm populations higher on these genotypes. Four of the five types had genes that confer high densities of simple, nonglandular trichomes, to some degree at the expense of glandular trichomes (Wo traits). Glandular trichomes probably provide some level of defense against insects, even in standard cultivars. The susceptibility of these four genotypes may be similar to that conferred toward the tobacco flea beetle [Epitrix hirtipennis (Melsheimer)] by a trichome-deficiency in lines possessing the af monogenic mutant (Rick et al., 1976). In our field test, mutant genotype LA 1663 (Wo and Ln traits) appeared to carry higher populations of the tobacco flea beetle on its foliage and even sustained breeding populations of the pepper weevil (Anthonomus eugenii Cano), which is rarely observed on tomato plants.

Genes conferring increased densities of nonglandular trichomes may provide some resistance to leafminers. Lines with hairy leaf traits sustained less damage by these insects. LA 1663 is an extremely hairy plant (due to the presence of two genes for excessive hairness) and was unique in that it sustained no damage by miners in either year. In previous studies, the pubescent breeding line, UF-763292, had significantly fewer Liriomyza sp. leaf mines than other cultivars and lines under natural infestations in Florida (Schuster, 1977; Schuster et al., 1979). A similar mecha-

Table 3. Correlation coefficients between damage to fruit in the field and characteristics of the fruit and vines of 40 genotypes in 1991.

\begin{tabular}{lcc}
\hline & \multicolumn{2}{c}{ Percentage of fruit damaged by: } \\
\cline { 2 - 3 } Vine characteristic & Beet armyworm & Hemipterans \\
\hline Wt per fruit & $0.450^{* *}$ & $0.467^{* \cdots}$ \\
Vine wt & $-0.533^{\cdots \cdots *}$ & $-0.571^{\ldots \ldots}$ \\
Percent ripe (harvest) & $0.029^{\text {ws }}$ & $0.161^{\text {*s }}$ \\
No. of fruit & $-0.483^{\cdots \cdots}$ & $-0.497^{\cdots \cdots}$ \\
Fruit : foliage wt & $0.390^{* *}$ & $0.577^{* \ldots}$ \\
\hline
\end{tabular}

Pearson coefficients $(r), \mathrm{n}=37$.

${ }^{* * * * * * * * * *} \mathrm{P}=0.05,0.01,0.005$, or 0.001 , respectively. 
Table 4. Survival (\%) of beet armyworm neonates on foliage of tomato test lines, survival and developmental characteristics of beet armyworm third instars on green fruit ( 5 weeks after anthesis) of the test lines. and cuticle toughness of fruit, expressed as resistance to penetration, used in bioassays.

\begin{tabular}{|c|c|c|c|c|c|c|}
\hline \multirow[b]{2}{*}{ Test line } & \multirow[b]{2}{*}{$\begin{array}{c}\text { On foliage } \\
\text { survival }(\%)^{\prime}\end{array}$} & \multicolumn{4}{|c|}{ On fruit } & \multirow[b]{2}{*}{$\begin{array}{l}\text { Fruit cuticle } \\
\text { resistance }(N)^{u}\end{array}$} \\
\hline & & Survival( $(\%)^{y}$ & Relative growth ${ }^{x}$ & $\begin{array}{c}\text { Days } \\
\text { to pupa* }\end{array}$ & $\begin{array}{c}\text { Days } \\
\text { to adult" }\end{array}$ & \\
\hline "Tiny Tim" & $79.7 \mathrm{a}$ & $1.6 \mathrm{~d}$ & $0.027 \mathrm{bc}$ & $25.0 \mathrm{a}$ & $31.0 \mathrm{a}$ & $4.00 \mathrm{a}$ \\
\hline 'T5' & $79.6 a$ & $20.6 a b c$ & $0.0 .56 \mathrm{ab}$ & $23.9 \mathrm{~b}$ & $29.5 \mathrm{ab}$ & $2.23 \mathrm{f}$ \\
\hline 'Bingo' & $79.1 \mathrm{a}$ & $28.6 \mathrm{abc}$ & $0.044 \mathrm{abc}$ & $15.6 \mathrm{~cd}$ & $23.2 \mathrm{c}$ & $2.86 \mathrm{~cd}$ \\
\hline LA 3-71 & $75.8 \mathrm{a}$ & $20.6 \mathrm{abc}$ & $0.031 \mathrm{bc}$ & $24.4 \mathrm{~b}$ & $29.9 \mathrm{ab}$ & $3.39 \mathrm{~b}$ \\
\hline LA 1606 & $75.4 \mathrm{a}$ & 9.5 bcd & $0.028 b c$ & $21.4 \mathrm{bcd}$ & $27.3 \mathrm{a}-\mathrm{e}$ & $2.31 \mathrm{ef}$ \\
\hline MW 18 & $73.2 \mathrm{a}$ & $25.4 \mathrm{ab}$ & $0.024 c$ & $22.1 \mathrm{bcd}$ & 28.8 a-d & $2.45 \mathrm{ef}$ \\
\hline MW 16 & $68.9 \mathrm{ab}$ & $27.0 \mathrm{abc}$ & $0.063 a$ & $17.3 \mathrm{~cd}$ & $24.1 \mathrm{c}-\mathrm{e}$ & $2.29 \mathrm{f}$ \\
\hline 'VFN 7718' & $67.8 \mathrm{ab}$ & $30.2 \mathrm{a}$ & $0.040 \mathrm{abc}$ & $18.1 \mathrm{~cd}$ & $23.8 \mathrm{de}$ & $2.29 \mathrm{f}$ \\
\hline UCN 28 & $64.3 \mathrm{ab}$ & $11.1 \mathrm{~cd}$ & $0.024 \mathrm{c}$ & $18.4 \mathrm{~cd}$ & $26.6 \mathrm{a}-\mathrm{e}$ & $2.98 \mathrm{c}$ \\
\hline LA 292 & $63.4 \mathrm{ab}$ & 15.9 a-d & $0.025 \mathrm{bc}$ & $22.3 \mathrm{bc}$ & $28.7 \mathrm{a}-\mathrm{d}$ & $2.62 \mathrm{de}$ \\
\hline LA 499 & $58.9 \mathrm{ab}$ & $11.1 \mathrm{~cd}$ & $0.024 b c$ & $16.9 \mathrm{~d}$ & $25.0 \mathrm{de}$ & $3.10 \mathrm{bc}$ \\
\hline MW 17 & $58.7 \mathrm{ab}$ & $17.5 \mathrm{a}-\mathrm{d}$ & $0.020 \mathrm{c}$ & $22.6 \mathrm{bc}$ & $29.2 \mathrm{abc}$ & $2.90 \mathrm{~cd}$ \\
\hline LA 1320 & $47.2 \mathrm{~b}$ & $1.6 \mathrm{~d}$ & $0.022 \mathrm{c}$ & $30.0 \mathrm{a}$ & --- & $278 \mathrm{~cd}$ \\
\hline PI 126449 & $2.3 \mathrm{c}$ & --- & --- & --- & $--\cdot$ & \\
\hline
\end{tabular}

${ }^{\mathrm{z}} \mathrm{F}=5.69 ; P=0.0001 ; \mathrm{df}=14,87$.

${ }^{\mathrm{y}} \mathrm{F}=2.19 ; P=0.0170 ; \mathrm{df}=12,116$

${ }^{\mathrm{x}}(\mathrm{mg} / \mathrm{mg}$ larva/day, over first 10 days of test $) \mathrm{F}=2.44 ; P=0.0116 ; \mathrm{df}=12,72$.

${ }^{\mathrm{w}} \mathrm{F}=5.62 ; P=0.0001 ; \mathrm{df}=12,135$.

${ }^{\mathrm{V}} \mathrm{F}=4.13: P=0.0001 ; \mathrm{df}=11,126$.

${ }^{\mathrm{v}} \mathrm{F}=20.80 ; P=0.0001 ; \mathrm{df}=12,123$.

Mean separation for all tests by LSD $(0.05)$. Values without letters were excluded from analysis because of zero variance.

Percentages were transformed to arcsin $\sqrt{x-1}$ before analysis.

nism could confer resistance in UF-763292 and LA 1663.

The data provide little evidence for strong multiple pest resistance in the test lines, except in the L. hirsutum entry. There are cases of possible antagonistic traits. Susceptibility of leafminerresistant LA 1663 to beetles has already been noted. Genes conferring extra hairiness may also be generally more susceptible to damage by beet armyworm as well (Table 1). 'Tiny Tim', relatively resistant to beet armyworm, appears to be particularly susceptible to damage by sucking insects (Table 1). Resistance to beet armyworm, however, may be positively associated with resistance to the tomato fruitworm and the tomato pinworm. Damage by these two insects was extremely low during both seasons. Additional evaluations under heavier pressure by these insects are needed to determine if there is general resistance to fruit-feeding Lepidoptera in some of the test lines.

\section{Literature Cited}

Brewer, M.J. and J.T. Trumble. 1991. Classifying resistance severity in field populalions: Sampling inspection plans for an insecticide resistance monitoring program. J. Econ. Entomol. 84:379-389.

Brewer. M.J., J.T. Trumble, B. Alvarado-Rodriguez, and W.E. Chaney, 1990. Beet armyworm (Lepidoptera: Noctuidae) adult and larval susceptibility three insecticides in managed habitats and relationship to laboratory selcc ion of resistance. J. Econ. Entomol. 83:2136-2146.

Canerday, T.D., J.W. Todd, and J.D. Dilbeck. 1969. Evaluation of tomatoes for fruitworm resistance. J. Georgia Entomol. Soc. 4:51-54.

Cantelo, W.W., A.L. Boswell, and R.J. Argauer. 1974. Tetranychus mite repellent in tomato. Environ. Entomol. 3:128-130.

Coggins, C.W., Jr., and L.N. Lewis. 1965. Some physical properties of the navel orange rind as related to ripening and to gibberellic acid treatments. Proc. Amer. Soc. Hort. Sci. $86: 272-279$.

Diawara, M.M.. J.T. Trumble, C.F. Quiros, and J.G. Millar. 1992. Resistance to Spodoptera exigua in Apium prostratum. Entomol. Expt. Applicata. 64:125-133.

Elliger, C.A., Y. Wong, B.G. Chan, and A.C. Waiss, Jr. 1981. Growth inhibitors in tomato (Lycopersicon) to the tomato fruitworm (Heliothis zea). J. Chem. Ecol. 7:753-

Farrar, R.A. and G.G. Kennedy. 1992. Sources of insect and mite resistance in tomato in Lycopersicon spp., p. 121-142 In: G. Kalloo (ed.). Monographs on theoretical and applied genetics. 14. Genetic improvement of tomato. Springer-Verlag.
Fery, R.L. and F.P. Cuthbert, Jr. 1973. Factors affecting evaluation of fruitworm resistance in the tomato. J. Amer. Soc. Hort. Sci. 98:457-459.

Fery, R.L. and F.P. Cuthbert, Jr. 1974. Resistance of tomato cultivars to the fruitworm. Heliothis zea (Boddie). HortScience 9:469-470.

Georghiou, G.P. 1986. The magnitude of the resistance problem. p. 14-44 In: Board on agriculture. NRC (eds). Pesticide resistance strategies and tactics for management. Natl. Acad. Press. NAS. Washington. D.C.

Gould. F. 1984. Role of behavior in the evolution of insect adaptation to insecticides and resistant host plants. Bulletin of the Entomological Society of America. 2434-41.

Isman, M.B. and S.S. Duffey. 1982. Toxicity of tomato phenolic compounds to the fruitworm, Heliothis zea. J. Amer. Soc. Hort. Sci. 107:167-170.

Juvik, J.A. 1980. Assessment of the alkaloid Oomatine, as a potential source of natural insect resistance in tomato cultivars. PhD Thesis. Univ. of California. Davis.

Juvik, J.A. and MA. Stevens. 1982. Physiological mechanisms of host-plant resistance in the genus Lycopersicon to Heliothis zea and Spodoptera exigua, two insect pests of the cultivated tomato. J. Amer. Soc. Hort. Sci. 107:1065-1069.

Juvik, J.A., M.A. Stevens, and CM. Rick. 1982. Survey of the genus I.ycopersicon for variability in alpha-tomatine content. HortScience 17:764-766.

Kashyap, R.K. and A.N. Verma. 1986. Factors imparting resistance to fruit damage by Heliothis armigero (Hübner) in some tomato phenotypes. Insect Sci. Application 8:111-114.

Kennedy, G.G., F. Gould, O.M.B. dePonti, and R.E. Stinner. 1987. Ecological, agriculrural. generic, and commercial considerations in the deployment of Insect-resistant germplasm. Environ. Entomol. 16:327-338.

Oatman, E.R. and G.G. Kennedy. 1976. Methomyl-induced outbreak of Liriomyza sativa on tomato. J. Econ. Entomol. 69:667-668.

Pasternak, D.M., M. Twersky, and V. DeMalach. 1979. Salt resistance in agricultural crops. p. 127-142. In: H. Mussel and R. Staples (eds.). Stress Physiology in crop plants. Wiley, New York.

Rick, C.M., C.F. Quiros, W.H. Lange, and M.A. Stevens. 1976. Monogenic control of resistance in the tomato to the tobacco flea beetle: Propable repellence by foliage volatiles. Euphytica 25:521-530.

SAS Institute. 1990. SAS/STAT User's Guide. SAS Institute. Cary N.C.

Schuster, D.J. 1977. Effect of tomato cultivars on insect damage and chemical control. Florida Entomologist 60:227-232.

Schuster. D.J., V.H. Waddill, J.J. Augustine, and R.B. Volin. 1979. Field comparisons of Lycopersicon accessions for resistance to the tomato pinworm and vegetable leafminer. J. Amer. Soc. Hort. Sci. 104:170-172.

Sinha, N.K. and D.G. McLaren. 1989. Screening for resistance to tomato fruitworm and cabbage looper among tomato accessions. Crop Sci. 29:861-868.

Sokal, R.R. and F.J. Rohlf. 1981. Biometry, 2nd ed. W.H. Freeman. San Francisco.

Tanaka. A.. K. Fukita, and K. Kikuchi. 1974. Nutro-physiological studies on the tomato plant III. Photosynthetic rate of individual leaves in relation to the dry matter production of plants. Soil Sci. Plant Nutr. 20:57-48. 